\title{
Tanggung Jawab Franchisor atas Kesalahan Branding Image Ditinjau Buku III Kitab Undang-Undang Hukum Perdata
}

\author{
Yohanes Jordan* \\ Prodi Ilmu Hukum, Fakultas Hukum, Universitas Islam Bandung, Indonesia.
}

*yohanesjordan@gmail.com

\begin{abstract}
Brand image, is an association of all available information about the products, services and companies of the brand in question. Image of the brand, associated with attitudes in the form of beliefs and preferences towards the brand. Positive belief in a brand, allows consumers to make purchases of products with that brand. The higher the brand image of a product, the higher the prestige value obtained by consumers. Franchising is a system in the marketing of goods and services that involves two parties (the franchisor and the franchisee), this system is a way to expand the business by transmitting success. Thus, in this system there must be a successful business actor first where the success he gets will be disseminated to other parties. In running a franchise business, the franchisor may make mistakes in carrying out policies for business continuity. because of a mistake in branding, their products, which were initially liked by the community, began to be abandoned by the community or even avoided by the community. The mistake made the public no longer trust and began to avoid the product which would have an impact on the sale of the product, the franchisee who did not make a mistake was also affected by the avoidance of the product they sold which resulted in losses to them. The purpose of this study is to understand how the franchisor is responsible for branding image errors that cause losses in franchise business activities. The results obtained that the franchisor's responsibility for branding image errors needs to be seen that the act is liability based on fault or contractual liability. if what is done violates the contract, the franchisee can ask the franchisor to pay compensation based on $1243 \mathrm{KUH}$ Perdata. However, if what is being done is against the law, the franchisee as the injured party must be able to prove the element of error committed by the franchisor that the act is indeed an unlawful act based $1865 \mathrm{KUH}$ Perdata.
\end{abstract}

Keywords: Brand Image, franchise agreement, accountability

Abstrak. Citra merek, merupakan asosiasi dari semua informasi yang tersedia mengenai produk, jasa dan perusahaan dari merek yang dimaksud. Citra terhadap merek, berhubungan dengan sikap yang berupa keyakinan dan prefensi terhadap merek. Keyakinan yang positif terhadap suatu merek, memungkinkan konsumen untuk melakukan pembelian terhadap produk dengan merek tersebut. Semakin tinggi citra merek suatu produk maka semakin tinggi pula nilai prestis yang didapat oleh konsumen. Waralaba merupakan suatu sistem dalam pemasaran barang dan jasa yang melibatkan dua pihak ( Franchisor dan Franchisee), sistem ini merupakan suatu kiat untuk memperluas usaha dengan cara menularkan sukses. Dengan demikian dalam sistem ini harus terdapat pelaku bisnis yang sukses terlebih dahulu dimana kesuksesan yang diperolehnya tersebut akan disebarluaskan kepada pihak lain. Dalam pelaksanaan usaha waralaba bisa saja terjadi kesalahan dari franchisor dalam menjalankan usahanya, karena kesalahan melakukan branding, produk mereka yang mulanya disukai oleh masyarakat, mulai ditinggalkan oleh masyarakat atau bahkan dihindari oleh masyarakat. Kesalahan tersebut membuat masyarakat tidak lagi mempercayai dan mulai menghindari produk tersebut yang tentunya berdampak terhadap penjualan produk tersebut, pihak franchisee yang tidak melakukan kesalahan pun ikut terkena dampak dari dihindarinya produk yang mereka jual yang mengakibatkan kerugian terhadap mereka. Tujuan dari penelitian ini adalah untuk memahami bagaimana pertanggungjawaban dari pemberi waralaba atas kesalahan branding image yang menyebabkan kerugian dalam kegiatan usaha waralaba. Hasil penelitian yang diperoleh bahwa pertanggungjawaban yang dilakukan franchisor atas kesalahan branding image perlu dilihat bahwa perbuatan tersebut termasuk dalam perbuatan melawan hukum atau perbuatan wanprestasi, jika yang dilakukan merupakan suatu perbuatan wanprestasi maka pihak franchisee dapat meminta pihak franchisor untuk membayar ganti rugi berdasarkan pasal 1243 KUH Perdata. Namun jika yang dilakukan merupakan perbuatan melawan hukum pihak franchisee selaku pihak yang dirugikan harus bisa membuktikan unsur kesalahan yang dilakukan oleh pihak franchisor bahwa perbuatan tersebut memang perbuatan melawan hukum, dengan kata lain beban pembuktian ada pada pihak penggugat sebagaimana yang ditetapkan pada pasal 1865 KUH Perdata.

Kata Kunci: Citra Merek, Perjanjian Waralaba, Pertanggungjawaban 


\section{A. Pendahuluan}

Citra merek merupakan jenis asosiasi yang muncul dalam benak konsumen ketika mengingat sebuah merek tertentu. Asosiasi tersebut secara sederhana dapat muncul dalam benak konsumen berbentuk pemikiran atau citra tertentu yang dikaitkan pada sebuah merek. Hubungan terhadap suatu merek akan semakin kuat jika didasarkan pada pengalaman dan mendapat banyak informasi. Citra atau asosiasi mempresentasikan persepsi yang bisa merefleksikan kenyataan yang objektif maupun tidak. Konsumen lebih sering membeli produk dengan merek yang terkenal lebih dapat diandalkan, selalu tersedia, mudah dicari, dan memiliki kualitas yang tidak diragukan, sehingga merek yang dikenal lebih sering dipilih konsumen daripada mereka yang tidak.

Dalam menjalankan usaha waralaba biasanya franchisor akan mengeluarkan usahausaha untuk mempertahankan bisnisnya, seperti kebijakan-kebijakan di bidang promosi, SOP mengenai produk dan manajemen, dan sebagainya yang tentunya untuk menjaga citra merek yang sudah ada. Dalam perjalanannya mengeluarkan kebijakan-kebijakan bisa saja pihak franchisor melakukan kesalahan dalam melakukan branding, karena kesalahan tersebut produk mereka yang mulanya disukai oleh masyarakat karena image dari brand yang buruk, mulai ditinggalkan oleh masyarakat atau bahkan dihindari oleh masyarakat. Kesalahan tersebut membuat masyarakat tidak lagi mempercayai dan mulai menghindari produk tersebut yang tentunya berdampak terhadap penjualan produk tersebut, pihak franchisee yang tidak melakukan kesalahan pun ikut terkena dampak dari dihindarinya produk yang mereka jual yang mengakibatkan kerugian terhadap mereka.

Kesalahan yang dilakukan oleh pemberi waralaba tersebut adalah seperti contoh kasus bedak bayi johnson yang ditemukan mengandung asbes yang dapat menyebabkan kanker, dengan adanya rumor tersebut mengakibatkan kepercayaan masyarakat terhadap produk bedak bayi tersebut menjadi menurun, yang dampaknya terhadap penjualan, atau karena perusahaan pemberi waralaba dapat dimisalkan menyatakan kepada publik bahwa perusahaan mereka mengakui dan/atau mendukung suatu hal yang oleh masyarakat pada umumnya tidak dapat diterima (contoh: mendukung LGBT) yang mengakibatkan sebagian masyarakat yang tidak suka akan keputusan perusahaan pemberi waralaba tersebut sehingga mulai memboikot produkproduk yang diproduksi oleh perusahaan tersebut dan tentu saja dengan adanya gerakan boikot tersebut dapat mempengaruhi terhadap penjual produk tersebut dan pihak penerima waralaba ikut terkena imbasnya.

Dengan adanya boikot maupun ketakutan masyarakat untuk menggunakan suatu produk menyebabkan produk tersebut mengalami penurunan dalam penjualan yang mempengaruhi pendapatan keuntungan bagi perusahaan atau perseorangan yang menjual produk tersebut dan bisa saja hingga mengalami kerugian karena produk tersebut tidak laku sama sekali.

Dengan adanya kerugian yang ditimbulkan, bagaimana pertanggungjawaban dari pihak pemberi waralaba kepada pihak penerima waralaba karena bisa saja dampak dari aksi boikot mempengaruhi usaha waralaba seperti penjualan yang menurun hingga penutupan usaha karena terus mengalami kerugian.

Berdasarkan latar belakang yang telah diuraikan, maka perumusan masalah dalam penelitian ini sebagai berikut: "Bagaimana pertanggungjawaban dari franchisor atas kesalahan branding image ditinjau dari buku III KUH Perdata?".

\section{B. Landasan Teori}

Menurut American Marketing Association mendefinisikan merek sebagai nama, istilah tanda, lambing, atau desain, atau kombinasinya, yang dimaksudkan untuk mengidentifikasikan barang atau jasa dari salah satu penjual atau kelompok penjual dan mendiferensiasikan mereka dari para pesaing.

Menurut Hogan, Citra merek (brand image), merupakan asosiasi dari semua informasi yang tersedia mengenai produk, jasa dan perusahaan dari merek yang dimaksud. Citra terhadap merek, berhubungan dengan sikap yang berupa keyakinan dan prefensi terhadap merek. Keyakinan yang positif terhadap suatu merek, memungkinkan konsumen untuk melakukan pembelian terhadap produk dengan merek tersebut. Menurut Kotler dan Keller, citra merek adalah proses dimana seseorang memilih, mengorganisasikan, dan mengartikan masukan 
informasi untuk menciptakan suatu gambaran yang berarti.

Semakin tinggi citra merek suatu produk maka semakin tinggi pula nilai prestis yang didapat oleh konsumen. Keberadaan merek merupakan kesanggupan seorang calon pembeli untuk mengenali atau mengingat kembali bahkan menjadi pelanggan setia produk tersebut. Oleh karena itu pentingnya menjaga dan mengembangkan citra merek merupakan hal yang harus dilakukan oleh perusahaan dalam melakukan strategi pemasaran.

Waralaba adalah perjanjian yang berisi pemberian hak kepada seseorang atau perusahaan untuk menggunakan merek dagang, atas barang atau jasa, berikut sistem bisnisnya oleh pemilik merek dagang tersebut. Sistem bisnis dalam kaitannya dengan perjanjian waralaba dapat meliputi kiat-kiat bisnis berupa metode-metode dan prosedur pembuatan, penjualan, dan pelayanan yang dilakukan oleh franchisor dan disini franchisor juga memberikan bantuan dalam periklanan dan promosi serta pelayanan konsultasi.

Adapun ciri-ciri atau elemen-elemen pokok yang terkandung dalam pengertian waralaba adalah:

1. Adanya hubungan hukum di antara franchisor dan franchisee sebagai akibat adanya perjanjian atas beban yang dibuat pihak-pihak tersebut.

2. Adanya pemberian izin untuk mempergunakan kekayaan berwujud dan/atau tidak berwujud dari franchisor kepada franchisee.

3. Adanya cara pendistribusian barang/pemasaran di bawah kendali metode franchisor.

4. Adanya penggunaan nama dagang dan/atau merek dagang milik franchisor oleh franchisee.

5. Adanya bimbingan pengelolaan franchisor terhadap unit bisnis milik franchisee yang dijalankan dengan nama dagang dan atau merek dagang franchisor.

6. Adanya sejumlah fee yang dibayarkan franchisee kepada franchisor.

Ganti rugi/ tanggung jawab dalam hukum perdata dapat timbul dikarenakan wanprestasi akibat dari suatu perjanjian atau dapat timbul dikarenakan oleh perbuatan melawan hukum. Ganti rugi yang muncul dari wanprestasi adalah jika ada pihak-pihak dalam perjanjian yang tidak melaksanakan kewajibannya yang sudah disepakati dalam perjanjian, maka menurut hukum ia dapat dimintai pertanggungjawaban, jika pihak lain dalam perjanjian tersebut menderita kerugian karenanya. Selain kerugian yang timbul dari wanprestasi, kerugian juga dapat ditimbulkan oleh perbuatan melawan hukum yang diatur dalam pasal 1365 KUH Perdata.

Perbuatan melawan hukum memiliki 2 (dua) pengertian, pengertian pertama adalah perbuatan melawan hukum dalam arti sempit yakni tiap perbuatan yang bertentangan dengan hak orang lain yang timbul karena undang-undang. Sedangkan ketentuan mengenai perbuatan melawan hukum dalam arti luas dikemukakan dan dipelopori oleh Molenggraaf, beliau mengatakan bahwa seseorang akan melakukan perbuatan melawan hukum, bilamana ia bertindak secara lain daripada yang diharuskan dalam pergaulan masyarakat mengenai seseorang atau benda lain.

Perbuatan melawan hukum dalam arti luas dapat diartikan dengan cukup luas yaitu:

1. Melanggar hak subyektif orang lain, berarti melanggar wewenang khusus yang diberikan oleh hukum kepada seseorang.

2. Bertentangan dengan kewajiban hukum pelaku, kewajiban hukum diartikan sebagai kewajiban yang berdasarkan hukum baik tertulis maupun tidak tertulis.

3. Bertentangan dengan kaedah kesusilaan, yaitu bertentangan dengan norma-norma moral, sepanjang dalam kehidupan masyarakat diakui sebagai norma hukum.

\section{Hasil Penelitian dan Pembahasan}

Pertanggungjawaban Franchisor atas kesalahan Branding Image yang menyebabkan kerugian dalam usaha waralaba

Dalam KUH Perdata terdapat 3 (tiga) kategori pertanggungjawaban hukum, yakni:

1. Tanggung jawab dengan unsur kesalahan (kesengajaan dan kelalaian) sebagaimana dinyatakan dalam pasal 1365 KUH Perdata;

2. Tanggung jawab dengan unsur kesalahan khsusnya kelalaian sebagaimana dinyatakan dalam pasal 1365 KUH Perdata; 
3. Tanggung jawab mutlak (tanpa kesalahan) sebagaimana terdapat dalam apsal $1367 \mathrm{KUH}$ Perdata

Pertanggungjawaban yang tertuang dalam pasal 1365 dan 1366 KUH Perdata mewajibkan adanya unsur kesalahan, artinya seseorang tersebut harus bersalah (liability based on fault). Asas pertanggungjawaban secara kesalahan (fault) didasarkan pada prinsip bahwa tidak ada pertanggungjawaban apabila tidak ada unsur kesalahan.

Selanjutnya pihak yang berkewajiban untuk membuktikan unsur kesalahan tersebut adalah pihak yang merasa dirugikan dengan kata lain beban pembuktian ada pada pihak penggugat sebagaimana yang ditetapkan pada pasal 1865 KUH Perdata yang berbunyi:

"Setiap orang yang mendalilkan bahwa ia mempunyai sesuatu hak, atau guna meneguhkan haknya sendiri maupun membantah suatu hak orang lain, menunjuk pada suatu peristiwa, diwajibkan membuktikan adanya hak atau peristiwa tersebut"

Selain prinsip liability based on fault yang terkandung dalam pasal 1365 KUH Perdata ada pula bentuk pertanggungjawaban yang berdasarkan pada adanya wanprestasi yang merupakan suatu contractual liability yang termaksud dalam pasal 1243 KUH Perdata yang berbunyi:

"Penggantian biaya, rugi dan bunga karena tidak terpenuhinya suatu perikatan, barulah mulai diwajibkan, apabila si berutang (debitur), setelah dinyatakan lalai memenuhi perikatannya, tetap melalaikannya, atau jika sesuatu yang harus diberikan atau dibuatnya, hanya dapat diberikan atau dibuat dalam tenggang waktu yang telah dilampaukannya".

Wanprestasi adalah suatu keadaan tidak terpenuhinya kewajiban yang seharusnya sebagaimana ditetapkan dalam perikatan atau perjanjian karena debitur tidak melaksanakan suatu prestasi atau kewajiban yang telah disepakati dalam perjanjian. Wanprestasi dapat terjadi karena dua hal yaitu karena kesalahan debitur baik karena sengaja maupun karena kelalaiannya dan karena keadaan memaksa (overmacht/force majeure). Akibat hukum dari terjadinya wanprestasi menurut KUH Perdata adalah:

1. Debitur diharuskan membayar gantu rugi (biaya, rugi, bunga) berdasarkan pasal 1243 KUH Perdata;

2. Kreditur dapat minta pembatalan perjanjian melalui Pengadilan berdasarkan pasal 1266 KUH Perdata;

3. Kreditur dapat meminta pemenuhan perjanjian, atau pemenuhan perjanjian disertai ganti rugi, atau pembatalan perjanjian dengan ganti rugi berdasarkan pasal 1267 KUH Perdata.

Dalam pertanggungjawaban yang dilakukan pemberi waralaba atas kesalahan branding image perlu dilihat bahwa perbuatan tersebut termasuk dalam perbuatan melawan hukum atau perbuatan wanprestasi, jika yang dilakukan merupakan suatu perbuatan wanprestasi maka pihak penerima waralaba dapat meminta pihak pemberi waralaba untuk membayar ganti rugi berdasarkan pasal 1243 KUH Perdata namun perlu ditekankan perbuatan yang dilakukan oleh pihak pemberi waralaba melanggar isi dari perjanjian waralaba. Namun berbeda apabila pihak pemberi waralaba tidak melakukan wanprestasi maka dapat meminta pertanggungjawaban karena telah melakukan perbuatan melawan hukum namun dalam hal ini pihak penerima waralaba selaku pihak yang dirugikan harus bisa membuktikan unsur kesalahan yang dilakukan oleh pihak pemberi waralaba bahwa perbuatan tersebut memang perbuatan melawan hukum, dengan kata lain beban pembuktian ada pada pihak penggugat sebagaimana yang ditetapkan pada pasal 1865 KUH Perdata.

\section{Kesimpulan}

Prinsip pertanggungjawaban perdata yang tertuang dalam pasal 1365 dan 1366 KUH Perdata mewajibkan adanya unsur kesalahan, artinya seseorang tersebut harus bersalah (liability based on fault), dan pihak yang merasa dirugikan berkewajiban untuk membuktikan unsur kesalahan tersebut dengan kata lain beban pembuktian ada pada pihak penggugat sebagaimana yang ditetapkan pada pasal 1865 KUH Perdata. Selain prinsip liability based on fault yang terkandung dalam pasal $1365 \mathrm{KUH}$ Perdata ada pula bentuk pertanggungjawaban yang berdasarkan pada adanya wanprestasi yang merupakan suatu contractual liability yang termaksud dalam pasal 1243 KUH Perdata. 


\section{Daftar Pustaka}

[1] Kitab Undang-Undang Hukum Perdata

[2] A Shimp Terence, periklanan promosi dan aspek tambahan komunikasi pemasaran . Terpadu, Jilid I, edisi 5, Jakarta: Penerbit Erlangga, 2003

[3] Kotler Philip, Keller Kevin Lane, Manajemen Pemasaran, edisi 13, Jakarta: Penerbit Erlangga, 2009

[4] M.A. Moegni Djojodirjo, Perbuatan Melawan Hukum, Cetakan Pertama, Jakarata: Pradnya Paramita, 1979

[5] Moch. Basarah dan M. Faiz Mufidi, Bisnis Franchise dan Aspek-aspek Hukumnya, Bandung: PT Citra Aditya Bakti, 2008

[6] Ratri, Lutiary Eka, Strategi Memenangkan Persaingan Pasar, Jakarta, Salemba Empat, 2007

[7] Septi Nuryani Dewi, Dede R. Oktini, Nina Maharani, Pengaruh Citra Merek Terhadap Minat Beli Sepatu Bata, Prosiding Manajemen Universitas Islam Bandung Vol. 3, No. 2, 2017

[8] Suri Amalia, M.Oloan, Pengaruh Citra Merek, Harga, dan Kualitas Produk Terhadap Keputusan Pembelian Handphone Merek Xiaomi di Kota Langsa, Jurnal Manajemen dan Keuangan Vol 6, No.1 2017

[9] Wirjono Prodjodikoro, Perbuatan Melanggar Hukum, Cetakan keenam, Bandung: Sumur Bandung, 1976

[10] Kontroversi Asbes dalam Bedak Bayo Johnson \& Johnson IDN Times. https://www.idntimes.com/news/indonesia/ita-malau/kontroversi-asbes-dalam-bedakbayi-johnson-johnson/3 diakses 6 juli 2021 pukul 18.56 